\title{
Antineoplastic Immune Cell
}

National Cancer Institute

\section{Source}

National Cancer Institute. Antineoplastic Immune Cell. NCI Thesaurus. Code C129826.

Any immune cell-based preparation that can be used or may potentially be used for its cytotoxic activity against cancer cells. 